\title{
Sequential Extraction and Particle Size Analysis of Heavy Metals in Sediments Dredged from the Deûle Canal, France
}

\author{
Nada Sabra ${ }^{1}$, Henri-Charles Dubourguier ${ }^{2}$ and Tayssir Hamieh*,1,3
}

\author{
${ }^{I}$ Faculty of Agricultural Engineering and Veterinary Medicine, Dekwaneh, Beirut, Lebanese University; ${ }^{2}$ Institut Supé- \\ rieur d'Agriculture de Lille, 59046, Lille Cedex, France; ${ }^{3}$ Laboratory of Materials, Catalysis, Environment and \\ Analytical Methods (MCEMA-CHAMSI) Faculty of Sciences, Lebanese University, Hariri Campus, Hadath, Beirut, \\ Lebanon
}

\begin{abstract}
The Deûle canal is one of the most polluted canals in northern France. It contains large volumes of polluted sediments. These have to be dredged and characterized before deciding about the technology suitable for their treatment. The sediments are thus subjected to a physico-chemical characterization comprising particle size classification and heavy metals sequential extraction studies. The total metallic concentrations exceed the French standards for several metals such as cadmium, zinc, lead or copper. On average, $92 \%$ of the total weight of each metal are present in the particles that are less than $53 \mu \mathrm{m}$ in size. These particles represent about $85 \%$ of the suspended matter dry weight. The sequential extraction study reveals that most of the studied metals are strongly linked to the sediments because of their association with the sulfides and with the organic matter.
\end{abstract}

Keywords: Canal, heavy metals, particle size analysis, pollution, sediment, sequential extraction.

\section{INTRODUCTION}

The Nord-Pas de Calais region in northern France counts $600 \mathrm{~km}$ of water channels [1] (DREAL Nord-Pas de Calais, 2007). Given its plane topography, large volumes of sediments are formed in the rivers and canals every year. Thee sediments need to be dredged periodically to prevent floods and avoid navigation problems. The volumes of sediments to be dredged are significant. They amounted to around 4.23 million $\mathrm{m} 3$ in 2007 and are expected to reach 8.4 million $\mathrm{m}^{3}$ of sediments between 2007 and 2027 [2]. In the absence of pollution, the dredged sediments can be deposited along the banks or on agricultural soils. However, in the occurrence of pollution, they need to be treated before reuse. This is unfortunately the case in the Nord Pas de Calais region which suffers from the pollution of its water channels due to the heavy industrial past of this region.. The dredged sediments are mainly contaminated with heavy metals and hydrocarbons [2]. Between the years 1990 and 2000, the volume of dredged sediments from the region has been estimated to 1.7 million $\mathrm{m}^{3}$. Seventy percent of the dredged and analyzed sediments were polluted [3]. The Deule canal is one of the most polluted water channels in the Nord Pas de Calais region. In 1998, the "Agence de l'Eau Artois-Picardie" [4] studied the biological quality of sediments by using oligochetes as biological indicators of pollution and found out that

*Address correspondence to this author at the Faculty of Agricultural Engineering and Veterinary Medicine, Dekwaneh, Beirut; Tel: 009611495 786; Fax:00 9611510 870; E-mails: tayssir.hamieh@ul.edu.lb, hamiehtayssir@yahoo.fr the Deule sediments ranked as highly contaminated class A sediments [4]. In a more recent study, the sediments of the Deule canal were found highly deteriorated and had a high pollution risk index requiring there in depth diagnosis [3].

Pagnanelli et al. [5] studied the sequential extraction of heavy metals in river sediments abandoned pyrite and Scheinost et al. [6] combined the selective sequential extractions for Quantitative Zinc Speciation in Soil. In india, the data modeling of heavy metal fractionation in sediments from Gomti River were studied by Singh et al. [7]; whereas the use of sequential leaching, mineralogy, morphology and multivariate statistical technique for quantifying metal pollution in polluted aquatic sediments were developed by Rath $e t$ al. [8]. On the other hand, Gómez Ariza et al. [9] studied to the extraction procedures for trace metal partitioning in sediments from south-west Spain.

Other studies were devoted to the heavy metal speciation in branch sediments of Poyang Lake [10], to the heavy metals partitioning in the sediments of Izmir Inner Bay [11] and to remobilization of metals from slag and polluted sediments [12].

The aim of this study is to conduct a physico-chemical characterization of sediments that have been dredged from the Deûle canal. This study would constitute a diagnosis of the sediments prior to their eventual treatment. Besides determining the total concentrations of heavy metals, the present work will study the distribution of these metals in the different granulometric and geo-chemical fractions of the sediments. 


\section{MATERIALS AND METHODS}

\section{General Characterization of the Sediments}

The sediments were sampled from the Deûle canal situated in the Nord-Pas de Calais region in northern France. Sampling was done from the point 080000 of the canal. This point is localized in the village of Haubourdin which is situated at the south of the city of Lille, the capital of northern France.

The sediments were digested then analyzed for their total heavy metal contents by inductively coupled plasma optical emission spectrometry (ICP-OES). For the digestion, $0.5 \mathrm{~g}$ of dry sediments were digested in $10 \mathrm{~mL}$ of concentrated nitric acid fhor 10 minutes in a microwave apparatus according to the EPA method 3051 [13]. The temperature of the samples should rise to $175^{\circ} \mathrm{C}$ in less than 5.5 minutes and remain between $170-180^{\circ} \mathrm{C}$ for 10 minutes and pressure must not exceed 6 atmospheres.

Organic matter and dry suspended matter (SM) contents were determined by centrifuging the samples at $8065 \mathrm{rpm}$ for 25 minutes, heating the solid residue to $550^{\circ} \mathrm{C}$ for 4 hours and $105^{\circ} \mathrm{C}$ for 2 hours and expressing the resulting dry weights as a function of the $105^{\circ} \mathrm{C}$ and fresh sample weights respectively.

\section{Particle Size Analysis}

For the particle size classification analysis, the sediments were wet sieved on a vibrating screen (Retch). Four sieves of $250 \mu \mathrm{m}, 180 \mu \mathrm{m}, 53 \mu \mathrm{m}$ and $25 \mu \mathrm{m}$ were used. A known weight of a wet homogenized sediment was introduced into the machine and water was run into the system. The particles greater than $25 \mu \mathrm{m}$ were collected into beakers after rinsing of the corresponding sieves with double distilled water and then oven dried at $105^{\circ} \mathrm{C}$ for 48 hours. The particles less than $25 \mu \mathrm{m}$ were collected by centrifuging the filtrate and then dried as previously. The centrifugation was carried out at $10^{\circ} \mathrm{C}$ and at $8065 \mathrm{rpm}$ for 25 minutes. The different granulometric fractions obtained were acid digested then analyzed for their total heavy metals content by ICP-OES as described above.

\section{Sequential Extraction of Heavy Metals from the Sedi- ments}

The sequential extraction scheme adopted was that developed by the "Measurements and Testing Programme" of the European Union. It was chosen because it is representative of most of the sequential extraction schemes present and because it has been validated by inter-laboratory comparison experiments and by certified reference materials $[14,15]$.

The sediments were air dried then sieved to $90 \mu \mathrm{m}$ prior to extraction. The extraction consisted of three main steps:

-Step one: one gram of dry sediment is extracted in a centrifuge tube with $40 \mathrm{ml}$ of $0.11 \mathrm{~mol} / \mathrm{L}$ acetic acid by shaking for 16 hours (overnight) at ambient temperature $\left(25^{\circ} \mathrm{C}\right)$. The extract or the acid soluble fraction comprises exchangeable and carbonate bound heavy metals. Their mobilization is governed by acid base equilibria;
- Step two: the residue from step one is rinsed with distilled water and then extracted for 16 hours (overnight) with $40 \mathrm{ml}$ of freshly prepared $0.1 \mathrm{~mol} / \mathrm{L}$ hydroxylamine hydrochloride acidified with nitric acid to $\mathrm{pH} 2$. The extract or the reducible fraction comprises heavy metals bound to Fe and Mn oxides and hydroxides. Their mobilization occurs under reducing conditions;

- Step three: the residue from step two is rinsed with distilled water then digested at room temperature for one hour with ten milliliters (mL) of $30 \% \mathrm{H}_{2} \mathrm{O}_{2}$ (adjusted to $\mathrm{pH}$ 2-3 with nitric acid). The digestion is carried out in the centrifuge tube after covering it with a watch glass. The tube is occasionally hand shaken during the digestion. The residue is then digested for one additional hour at $85^{\circ} \mathrm{C}$. At the end of the digestion, the watch glass is removed and the volume reduced to a few $\mathrm{mL}$. Ten milliliters of the $\mathrm{H}_{2} \mathrm{O}_{2}$ solution are then added and the same digestion $\left(85^{\circ} \mathrm{C}, 1\right.$ hour $)$ and volume reduction procedure is repeated. $50 \mathrm{~mL}$ of $1 \mathrm{~mol} / \mathrm{L}$ ammonium acetate solution adjusted to $\mathrm{pH} 2$ with acetic acid are added to the residue and the latter is extracted for 16 hours (overnight). The extract or the oxidizable fraction comprises heavy metals bound to the sulfides and to the organic matter. Their mobilization occurs under strong oxidizing conditions.

The solid residue left at the end of these extraction steps represents the residual fraction. It comprises heavy metals that are strongly bound to the crystalline lattice of the sediments and which can not be released by any of the reagents used in the previous steps

Shaking is done on a horizontal shaking table. The sediments must be continually in suspension during the extraction. The extracts are filtered through a $0.45 \mu \mathrm{m}$ membrane prior to ICP determination.

\section{RESULTS AND DISCUSSION}

\section{General Characterization of the Sediments}

According to Table 1, the sediments have a fine texture as the particles having less than $50 \mu \mathrm{m}$ in diameter represent more than $50 \%$ of the dry suspended matter (SM) weight. The sediments are also rich in organic matter as the organic matter percentage is greater than the mean values $(2-10 \%)$ found in the sediments of the Nord Pas de Calais region.

To assess the level of contamination and in the absence of French standards specific for sediments, the total concentrations of heavy metal were compared to the French soil standards, which are values above which, no sediment or sludge application is allowed on a given soil. The sediments were not polluted by $\mathrm{Cr}$ as its concentration was below the soil standard. The contamination of the sediments was slight in the case of $\mathrm{Cu}$ but high in the case of $\mathrm{Pb}, \mathrm{Zn}$ and $\mathrm{Cd}$. Although no legislation exists at the present time for $\mathrm{Mn}$, we can notice the high load of the sediments in this metal as its concentration is superior to the Natural Values, which are values below which a given soil is considered as not polluted. The metal concentrations were also higher than the sludge standards which are values above which no sludge 
Table 1. Characteristics of the Sediments Dredged from the Deûle Canal in the Haubourdin Region at the Point 080000

\begin{tabular}{|c|c|c|c|c|}
\hline Parameters & French Soil Standards ${ }^{\alpha}$ & $\begin{array}{l}\text { French Sludge } \\
\text { Standards }{ }^{\alpha}\end{array}$ & Natural Salues $^{\mathrm{b}}$ & Results \\
\hline$\% \mathrm{SM}^{\beta}$ (with respect to fresh sediment weight) & $-\gamma$ & - & - & 21.3 \\
\hline Particles less than $50 \mu \mathrm{m}$ as a $\%$ of SM & - & - & - & 84.5 \\
\hline$\%$ organic matter (with respect to $\% \mathrm{SM}$ ) & - & - & - & 14.02 \\
\hline Iron (mg/kg of SM) & $-{ }^{\delta}$ & - & 10000 & 24225 \\
\hline Manganese (mg/kg of SM) & - & - & 250 & 428 \\
\hline Copper (mg/kg of SM) & 100 & 1000 & 20 & 145 \\
\hline Zinc (mg/kg of SM) & 300 & 3000 & 75 & 6014 \\
\hline Lead (mg/kg of SM) & 100 & 800 & 20 & 1222 \\
\hline Chromium (mg/kg of SM) & 150 & 1000 & 25 & 130 \\
\hline Cadmium (mg/kg of SM) & 2 & 20 & 0.5 & 475 \\
\hline
\end{tabular}

${ }^{\alpha}$ : From Ref. [16]

b: From Ref. [17]

: SM : Suspended matter

$\gamma$ : No data available

${ }^{\delta}:$ No standards available

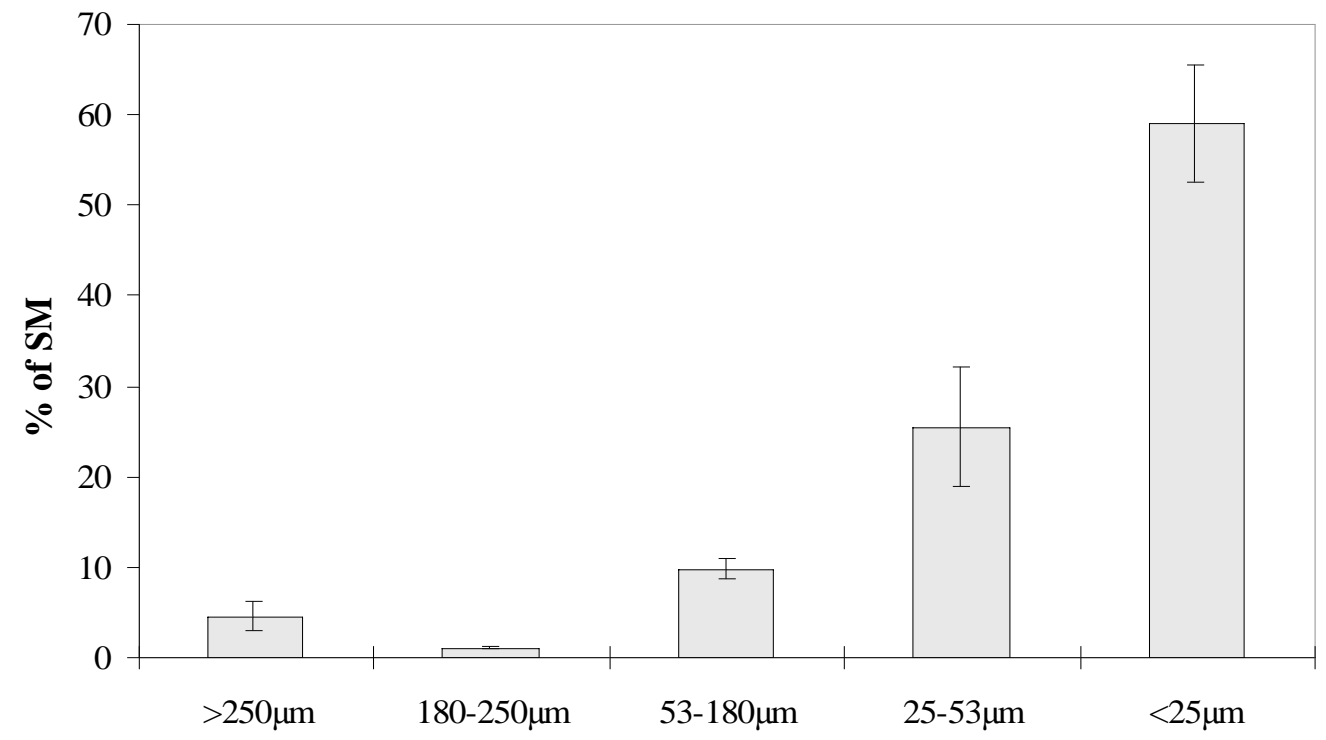

Granulometric fractions

Fig. (1). Percentages of the dry suspended matter weight for the different granulometric fractions.

from waste water treatment plants or other assimilated material can be deposited on the soil.

\section{PARTICLE SIZE ANALYSIS}

Twenty replicate sediment samples were analyzed. The experimental error was small as the values of the standard deviation ranged from $0.1 \%$ for the fraction $250-180 \mu \mathrm{m}$ to $6.25 \%$ for the fraction less than $25 \mu \mathrm{m}$.

According to (Fig. 1), about $60 \%$ of the dry suspended matter content consist of particles less than $25 \mu \mathrm{m}$ in diame- ter. This fraction is mainly composed of clays and fine loam. The fraction between $25 \mu \mathrm{m}$ and $53 \mu \mathrm{m}$ corresponds to the coarse loam particles and constitute $25.5 \%$ of the dry SM. Globally, the fraction less than $53 \mu \mathrm{m}$ represents $84.5 \%$ of the dry SM.

\section{DISTRIBUTION OF HEAVY METALS IN THE DIF- FERENT GRANULOMETRIC FRACTIONS}

The precision of the experiment was checked by calculating over the twenty granulometric trials a mass balance based on the total heavy metals and suspended dry matter 
Table 2. Concentrations of Heavy Metals (mg/kg SM) in the Different Granulometric Fractions and Mass Balances Calculated on 20 Granulometric Trials

\begin{tabular}{|c|c|c|c|c|c|c|c|}
\hline Fraction & $\mathbf{P b}$ & Cd & $\mathbf{Z n}$ & $\mathbf{F e}$ & $\mathrm{Cr}$ & $\mathbf{C u}$ & Mn \\
\hline$>250 \mu \mathrm{m}$ & 18.9 & 3.0 & 71.8 & 627 & 1.7 & 7.6 & 17.3 \\
\hline $250-180 \mu \mathrm{m}$ & 6.3 & 0.7 & 19.7 & 167 & 0.7 & 0.9 & 4.0 \\
\hline $180-53 \mu \mathrm{m}$ & 70.5 & 9.5 & 211 & 2086 & 6.7 & 8.1 & 26.9 \\
\hline $53-25 \mu \mathrm{m}$ & 181 & 52.4 & 752 & 4268 & 19.6 & 20.2 & 79.5 \\
\hline$<25 \mu \mathrm{m}$ & 931 & 408.2 & 4944 & 15167 & 98.1 & 147.6 & 259.8 \\
\hline Rinsing water & 6.7 & 2.4 & 12.1 & $<$ d.l. & 3.4 & $<$ d.l. & $<$ d.l. \\
\hline Total calculated concentrations & 1214 & 476.2 & 6010 & 22315 & 130.1 & 184.5 & 387.5 \\
\hline Total measured concentrations & 1222 & 474.6 & 6014 & 24225 & 129.7 & 144.8 & 428.1 \\
\hline French soil standards* & 100 & 2.0 & 300 & & 150 & 100 & \\
\hline
\end{tabular}

d.1. : detection limit $(\mathrm{mg} / \mathrm{kg} \mathrm{SM})$

*: From Ref. [16]

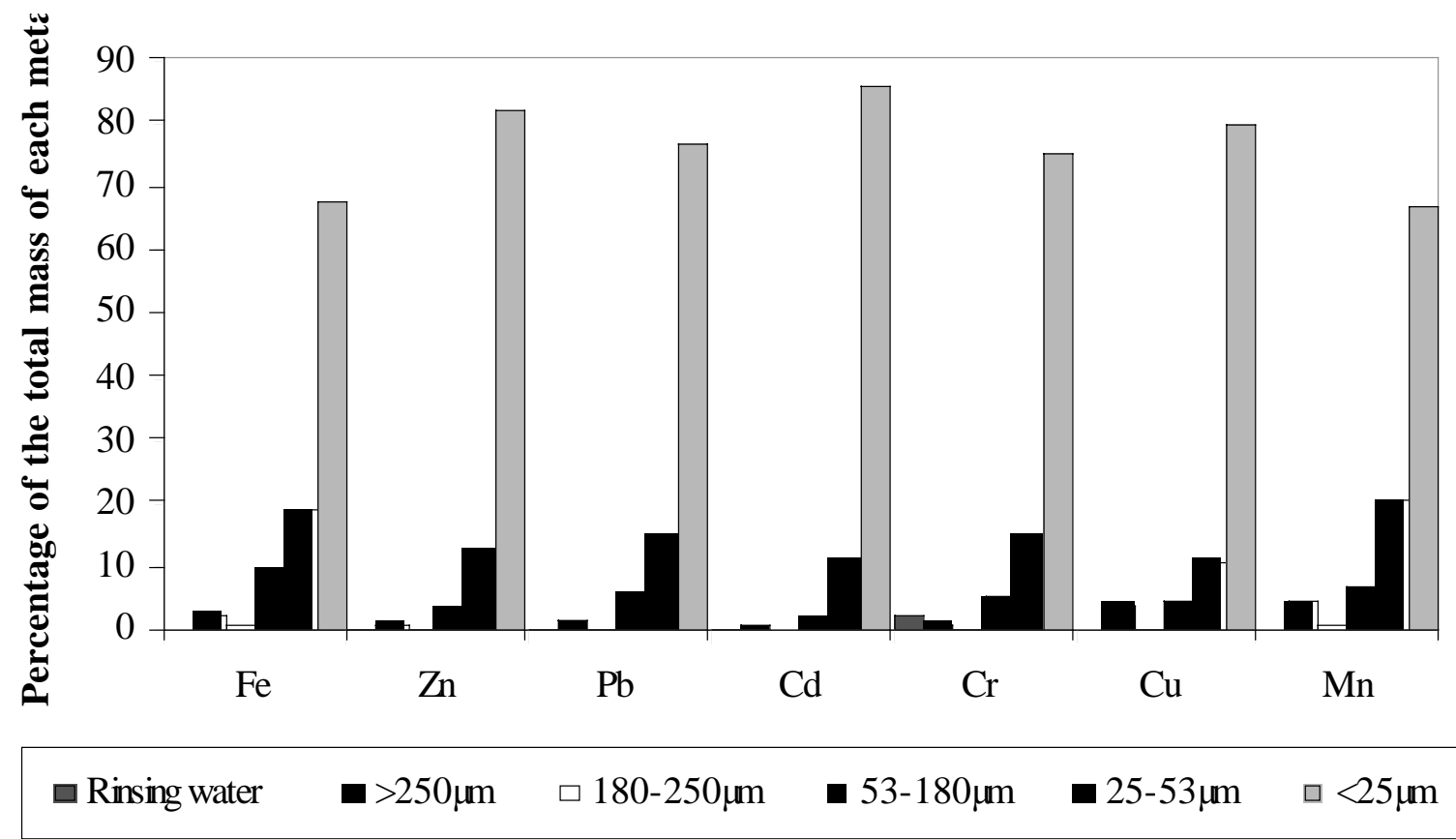

Fig. (2). Percentages of the total mass of each heavy metal in the different granulometric fractions.

contents of the different granulometric fractions obtained. Table 2, shows that the theoretical total heavy metals concentrations as calculated from the mass balance are close to the total measured heavy metals concentration.

According to (Fig. 2), heavy metals are generally more concentrated in the fine granulometric fractions than in the coarse ones. The particles less than $25 \mu \mathrm{m}$ contain the greatest concentration of heavy metals. On average, $77 \%$ of the mass of each metal are present in the fraction less than $25 \mu \mathrm{m}$ in diameter. The value is equal to $14.5 \%$ for the $25-53 \mu \mathrm{m}$ fraction and is less than $10 \%$ for the fractions greater than $53 \mu \mathrm{m}$. On the other hand, the rinsing water contained negligible concentrations of heavy metals. Globally, $92 \%$ of the metallic load are thus present in the particles less than $53 \mu \mathrm{m}$ which represent alone $84.5 \%$ of the suspended dry weight of the sediments. The predominant association of the heavy metals with the fine fractions of the sediments has also been observed by Kern and Westrich [18] and by Brandvold et al. [19]. This correlation between the heavy metals load and the size of the fine particles was however not observed by Stone and Marsalek [20] because the sediments used in their study were mostly composed of sand particles.

The high pollution load and the elevated dry SM percentage of the particles less $53 \mu \mathrm{m}$ might be favorable for a future isolation of these particles from the rest of the sediment and for the limitation of any heavy metal treatment to this fine fraction only. This would limit the future treatment of the sediment to the treatment of the fine polluted fractions only 
Table 3. Mean Concentrations of Heavy Metals (mg/kg Dry Fraction) of the Different Granulometric Fractions Calculated on 20 Granulometric Trials

\begin{tabular}{|c|c|c|c|c|c|c|c|}
\hline & $\mathbf{P b}$ & $\mathbf{Z n}$ & Cd & $\mathbf{C u}$ & $\mathrm{Cr}$ & $\mathbf{F e}$ & Mn \\
\hline Total concentration in sediments & 1222 & 6014 & 474.5 & 145 & 130 & 24225 & 428 \\
\hline $\begin{array}{l}\text { Concentration in the fraction }>25 \mu \mathrm{m} \\
\qquad 41 \% \text { of the SM }\end{array}$ & $753 \pm 44$ & $2727 \pm 260$ & $156.7 \pm 28$ & $110 \pm 18$ & $76 \pm 4$ & 20436 & 357 \\
\hline $\begin{array}{l}\text { Concentration in the fraction }<25 \mu \mathrm{m} \\
559 \% \text { of the SM }\end{array}$ & $1688 \pm 19$ & $8961 \pm 172$ & $739.8 \pm 22$ & $268 \pm 16$ & $178 \pm 4$ & 27490 & 471 \\
\hline $\begin{array}{l}\text { Concentration in the fraction }>53 \mu \mathrm{m} \\
\qquad 15,5 \% \text { of the SM }\end{array}$ & $722 \pm 45$ & $2284 \pm 74$ & $100 \pm 6$ & $126 \pm 26$ & $69 \pm 5$ & 21750 & 364 \\
\hline $\begin{array}{l}\text { Concentration in the fraction }<53 \mu \mathrm{m} \\
\qquad 84.5 \% \text { of the SM }\end{array}$ & $1355 \pm 13$ & $6854 \pm 36$ & $550 \pm 13$ & $201 \pm 6$ & $144 \pm 4$ & $24232 \pm 23$ & $426 \pm 2.5$ \\
\hline Sludge standards & 800 & 3000 & 20 & 1000 & 1000 & ${ }_{-}^{\alpha}$ & - \\
\hline Soil standards & 100 & 300 & 2 & 100 & 150 & - & - \\
\hline $\begin{array}{l}\text { Maximal metallic concentrations in the sediments } \\
\text { in order to respect the sludge standards after a } \\
\text { granulometric classification at } 53 \mu \mathrm{m}\end{array}$ & 1354 & 7900 & 95 & 1150 & 1886 & $-\beta$ & - \\
\hline $\begin{array}{l}\text { Maximal metallic concentrations in the sediments } \\
\text { in order to respect the soil standards after a granu- } \\
\text { lometric classification at } 53 \mu \mathrm{m}\end{array}$ & 169 & 790 & 9.5 & 115 & 283 & - & - \\
\hline
\end{tabular}

${ }^{\alpha}$ _. no standards available

-: no data available

and would reduce both the cost and the duration of the treatment.

However, the observation of Table 3 shows that such isolation would not be applicable in the case of the studied sediments because the particles greater than $53 \mu \mathrm{m}$ would still be above the French standards. It follows that any eventual metal remediation technology should be applied to the total volume of the sediments.

\section{SEQUENTIAL EXTRACTION OF THE HEAVY METALS FROM THE SEDIMENTS}

The sequential extraction study has been mainly limited to the heavy metals for which the French soil standards existed and that were present in concentrations above those standards. The heavy metals studied were $\mathrm{Cd}, \mathrm{Pd}, \mathrm{Cu}$ and $\mathrm{Zn}$. Mn was also included in this study. According to (Fig. $3)$, all studied heavy metals are not concentrated in the residual fraction. The predominant presence of the metals in fractions other than the residual fraction has been correlated to the importance of the heavy metal load by Bodog et al. [21] and Hlavay and Polyak [22].

On the other hand, (Fig. 3), shows that most of the studied metals $(\mathrm{Cu}, \mathrm{Pb}$ and $\mathrm{Cd})$ are mainly associated with the sulfides and with the organic matter fraction. Zn and especially $\mathrm{Mn}$ are mainly linked to the acid-soluble and reducible fractions of the sediments.

Our findings are close to results found by other researchers. The predominant association of $\mathrm{Cu}$ with the organic matter fraction and of $\mathrm{Zn}$ with the reducible fraction have been observed by Yu et al. [23-24] Tsai et al [25] and Usero et al. [26]. On the other hand, the concentration of $\mathrm{Pb}$ in the oxidizable fraction has been recorded by Mester et al. [27]. In general, the presence of most heavy metals in the organic and reducible fractions is due to the fact that organic matter and Fe-oxides are more accessible to heavy metals than other sediment phases [28]. Close findings were also reported by Yu et al. [29] who found that the acid volatile sulfides have the priority to bind to heavy metals followed by organic matter and carbonates.

As the extraction of heavy metals from the oxidizable fraction occurs under more severe conditions in comparison to the acid soluble and reducible fractions, it appears that $\mathrm{Pb}$, $\mathrm{Cd}$ and $\mathrm{Cd}$ are more tightly linked to the sediment matrix in comparison to $\mathrm{Mn}$ and $\mathrm{Zn}$. It can also be estimated that the heavy metals can be ranked according to a decreasing mobility order as follows: $\mathrm{Mn}>\mathrm{Zn}>\mathrm{Cd}>\mathrm{Cu}>\mathrm{Pb}$.

The repartition of heavy metals in the different geochemical fractions of the sediments and their subsequent mobility depends on several factors particularly the nature of the sediments as well and the concentration of the heavy metals. For instance, Howari and Banat [28] assessed heavy metal pollution in the Yarmouk and Jordan rivers in Jordan. Compared to the sediments of the Deule canal, the sediments of the Jordan and Yarmouk rivers contain higher levels of sand $(50-51 \%)$ and lower levels of organic matter $(1.9 \%$ $2 \%)$ and fine particles $(46 \%-53 \%$ for the particles less than $50 \mu \mathrm{m})$. Also, the concentrations of $\mathrm{Pb}, \mathrm{Zn}$ and $\mathrm{Cd}$ in the sediments of both rivers reflected background values. The 


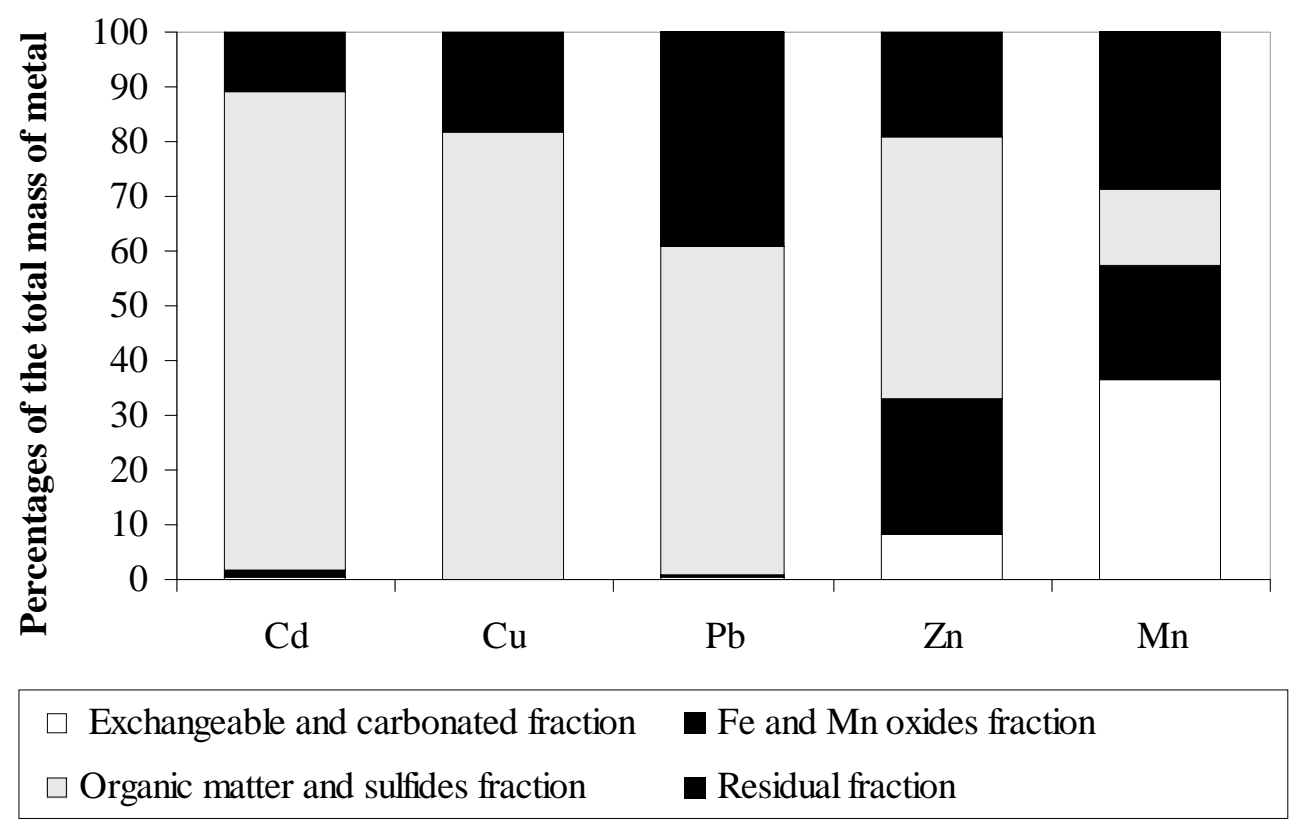

Fig. (3). Heavy metals distribution in the different chemical fractions of the sediments as a percentage of the total mass of each metal.

sequential extraction study revealed that most of the sediments were predominatly associated to the residual fraction and thus of low mobility, a fact in accordance with Bodog et al., [21] and Hlavay and Polyak, [22]. As for the mobility of heavy metals, it was close to that recorded for the Deule canal $(\mathrm{Cd}>\mathrm{Zn}>\mathrm{Pb}$ for Jordan sediments and $\mathrm{Zn}>\mathrm{Cd}>\mathrm{Pb}$ for Yarmouk sediments). Despite this similarity, it is important to note that the mobility of heavy metals in the two studies has been determined by different factors namely different sediment composition and different pollution loads and age.

The estimation of the relative mobility of the studied heavy metals bears a special importance as the determination of the total heavy metals concentrations is not sufficient to estimate the mobility of the heavy metals in the sediments or the actual toxicity of these sediments [29]. The results of the sequential extraction study need to be taken into consideration when applying any metal remediation technology to the sediments in the future. These can be physical such as the solidifcation/stabilization process, chemical like the chemical washing of sediments or biological such as the bioleachning of heavy metals from the sediments or phytoremediation [30-33]. Of the different technologies that can be adopted, bioremediation technolgies based on the bioleaching of heavy metals from the sediments are to be chosen as they are efficient, cost effective and natural [34-35].

\section{CONCLUSIONS}

In this paper, the physico-chemical characterization of the sediments, the particle size classification and the heavy metals sequential extraction were studied. The general characterization of the sediments revealed that they were highly polluted with the heavy metals. The total metallic concentrations exceed the French standards for several metals such as cadmium, zinc, lead or copper. According to the grain size analysis, the sediments were mainly constituted of clays and fine loams. The analysis also showed that the heavy metals were predominantly associated with the fine particles less than $53 \mu \mathrm{m}$. These particles represent about $85 \%$ of the suspended matter dry weight. The high metal levels in most sediment fractions do not allow the pretreatment of the sediments by grain size classification. Such pretreatment would be more suitable for sediments with comparable granulometric composition but with a lower pollution load. The sequential extraction study showed that most of the studied metals were tightly linked to the matrix because of their association with the organic matter and the sulfides.

\section{ACKNOWLEDGMENTS}

The authors thank Mr. H.C. Dubourguier for his assistance and the "Agence de l'Eau Artois-Picardie", the "Conseil Régional Nord-Pas de Calais" and the "Direction Régionale pour l'Environnement in France" for their financial contribution to this study. Thanks are also expressed to the laboratories CREID and AGREN for conducting the heavy metals analyses.

\section{REFERENCES}

[1] Direction Régionale de l'Environnement, de l'Aménagement et du Logement.: 2007, "Situation du Nord Pas de Calais, DRIRE Nord Pas-de-Calais - IRE 2007 - SOLS 352", 2007, Avalable at: http://www.nord-pas-de-calais.developement-durable.gouv.fr.

[2] Ministère du Développement Durable, Direction Régionale des Voies Navigables de France, Service de la Navigation du Nord-Pas de Calais.: 2009, "Schéma Directeur Régional des Terrains de Dépôts". Available from: http://www.sn-nord-pas-de-calais.develo ppement-durable.gouv.fr/rubrique.php3?id_rubrique $=219$. Last site update 25/6/2009

[3] Ministère de l'Ecologie et du Développement Durable/Ministère de l'Aménagement du Territoire et de l'Environnement/Agences de 1'Eau/Royal Haskoning,: 2002. "Etudes sur l'eau en France, Rapport No. 89, Historique National des Opérations de Curage et Perspectives, rapport de synthèse".

[4] Agence de l'Eau Artois-Picardie/BURGEA région CentreEst/CEMAGREF.: 1998. "Utilisation des oligochètes et indices oli- 
gochètes pour l'évaluation du risque écologique lié à la présence de micropolluants minéraux et organiques dans les sédiments du bassin Artois-Picardie. Rapport de synthèse, RLy 381 a/ A.5484, 1998", Av. from: http://portaildoc.oieau.fr/entrepotsOAI/AEAP/26/ 132830/132830_doc.pdf

[5] F. Pagnanelli, E. Moscardini, V. Giuliano, and L. Toro, "Sequential extraction of heavy metals in river sediments abandoned pyrite", Environmental Pollution, vol. 132, no. 2, pp. 189-201, 2004.

[6] A. C. Scheinost, R. Kretzschmar, S. Pfister, and D. R. Roberts, "Combining selective sequential extractions, X-ray absorption spectroscopy, and principal component analysis for quantitative zinc speciation in soil", Environmental Science \& Technology, vol. 36, no. 23, pp. 5021, 2002.

[7] K. P. Singh, A. Malik, N. Basant, V. K. Singh, A. Basant, "Multiway data modeling of heavy metal fractionation in sediments from Gomti River (India)", Chemometrics and Intelligent Laboratory Systems, vol. 87, no. 2, pp. 185-193, 2007.

[8] P. Rath, U. C. Panda, D. Bhatta, and K. C. Sahu, "Use of sequential leaching, mineralogy, morphology and multivariate statistical technique for quantifying metal pollution in highly polluted aquatic sediments-A case study: Brahmani and Nandira Rivers, India, 2009”, Journal of Hazardous Materials, vol. 163, no. 2-3, pp. 632644, 2009.

[9] J. L. Gómez Ariza, I. Giráldez, D. Sánchez-Rodas, and E. Morales, "Comparison of the feasibility of three extraction procedures for trace metal partitioning in sediments from south-west Spain", The Science of the Total Environment, vol. 246, no. 2-3, pp. 271-283, 2000.

[10] M. Luo, J. Li, W. Cao, M. Wang, "Study of heavy metal speciation in branch sediments of Poyang Lake", Journal of Environmental Sciences, vol. 20, no. 2, 161-166, 2008.

[11] D. E. Guven, and G. Akinci, "Heavy metals partitioning in the sediments of Izmir Inner Bay". Journal of Environmental Sciences, vol. 20, no.4, pp. 413-418, 2008.

[12] N. Vdović, G. Billon, C. Gabelle, and J.L. Potdevin. "Remobilization of metals from slag and polluted sediments (Case Study: The canal of the Deûle River, northern France)", Environmental Pollution, vol. 141, no. 2, pp. 359-369, 2006.

[13] U.S. Environmental Protection Agency.: 2003, "EPA method 3051: microwave acid assisted digestion of sediments, sludges, soils and oils", Available from www.epa.gov/epaoswer:hazwaste/test/ 3_series.htm.

[14] Ph. Quevauviller, G. Rauret, J.-F. Lopez-Sanchez, R. Rubio, A. Ure, A., and H. Muntau, "Certification of trace metal extractable contents in a sediment reference material (CRM 601) following a three-step sequential extraction procedure", The Science of the Total Environment, vol. 205, pp. 223-234, 1997.

[15] P. Quevauviller, G. Rauret, H. Muntau, A. M. Ure, R. Rubio, R. J. F. Lopez-Sanchez, H. D. Fiedler, and B. Griepink, "Evaluation of sequential extraction procedure for the determination of extractable metal contents in sediments", Fresenius' Journal of Analytical Chemistry, vol. 349, pp. 808-814, 1994.

[16] Journal Officiel de la République Française.: 1998, "Arrêté du 8 Janvier 1998- Épandage des boues STEP".vol. 26, pp. 1563-1571, 1998.

[17] Agence de l'Eau Artois-Picardie.: 1997, "La qualité des sédiments et des cours d'eau; étude 1991-1996"., Av. from: http://www.eauartois-picardie.fr.

[18] U. Kern, and B. Westrich, "Sediment contamination by heavy metals in a lock-regulated section of the river Neckar", Marine and Freshwater Research vol. 46, pp. 101-106, 1995.

[19] L. A. Brandvold, V. T. McLemore, C. O'Connor, and D. K. Brandvold, "Distribution and partioning of copper, lead and zinc in stream sediments above and below an abandoned mining and milling area near Pecos, New Mexico", USA, Analyst, vol. 120, pp. 1485-1495, 1995.

[20] M. Stone, and J. Marsalek, "Trace metal Composition and Speciation in Street Sediments : Sault St Marie, Canada", Journal of Water, Air and Soil Pollution. vol. 83, pp. 1-21, 1995.

[21] I. Bodog, K. Polyak and J. Hlavay, "Determination of heavy metals in lake and river sediments by selective leaching", International Journal of Environmental and Analytical Chemistry. vol. 66, pp. 79-94, 1997.

[22] J. Hlavay, and K. Polyak, "Chemical speciation of elements in sediment samples collected at lake Balaton", Microchemical Journal. vol. 58, pp. 281-290, 1998.

[23] K. C. Yu, L. J. Tsai, S. H. Chen, and S. T. Ho, "Chemical binding of heavy metals in anoxic river sediments", Water Research. vol. 35, no. 17, pp. 4086-4094, 2001.

[24] K. C. Yu, L. J. Tsai, S. H. Chen, and S. T. Ho, "Correlation analyses on binding behavior of heavy metals with sediment matrices", Water Research. vol. 35, no. 10, pp. 2417-2428, 2001.

[25] L. J. Tsai, K. C. Yu, S. F. Chen, P. Y. Kung, C. Y. Chang, and C. H. Lin, "Partinioning variation of heavy metals in contaminated river sediment via bioleaching: effect of sulfur added to total solids ratio", Water Research. vol. 37, pp. 4623-4630, 2003.

[26] J. Usero, M. Gamero, J. Morillo, and I. Gracia, "Comparative study of three sequential extraction procedures for metals in marine sediments", Environment International. vol. 24, no. 4, pp. 487-496, 1998.

[27] Z. Mester, C. Cremisini, E. Ghiara, and R. Morabito, "Comparison of two sequential extraction procedures for metal fractionnation in sediment samples", Analytica Chimica Acta, 359, pp. 133-142, 1998

[28] F. M. Howari, and K. M. Banat, "Assessment of Fe, Zn, Cd, $\mathrm{Hg}$, and $\mathrm{Pb}$ in Jordan and Yarmouk river sediments in relation to their physicochemical properties and sequential extraction characterization", Water, Air and Soil Pollution. vol. 132, pp. 43-59, 2001.

[29] C. M. Davidson, A. L. Duncan, D. Littlejohn, and A. M. Ure, "A critical evaluation of the three-stage BCR sequential extraction procedure to assess the potential mobility and toxicity of heavy metals in industrially-contaminated land", Analytica Chimica Acta, vol. 363, pp. 45-55, 1998.

[30] W. Rulkens, "Introduction to the treatment of polluted sediments", Reviews in Environmental Science and Bio/Technology, vol. 4, pp. 21-221, 2005.

[31] A. Bhandari, R. Y. Surampalli, P. Champagne, S. K. Ong, R. D. Tyagi, and M.C. Lo, I. Eds., "Remediation Technologies for Soils and Ground Water". American Society of Civil Engineers, Virginia., 2007.

[32] P. Lecomte, "Traitement des Sols et des Eaux Souterraines". $2^{\text {eme }}$ édition. Tec \&Doc Lavoisier, Paris. 1998.

[33] U.S. Environmental Protection Agency, "Selecting remediation techniques for contaminated sediment". 1993, Document No. EPA823-B93-001, pp. 226.

[34] S. Y. Chen, and J. G. Lin, "Bioleaching of heavy metals from contaminated sediment by indegenous sulfur-oxidizing bacteria in airlift bioreactor: effect of sulfur concentration", Water Research. vol. 38, pp. 3205-3214, 2004.

[35] D. Fang, L. Zhao, Z. Q. Yang, H. X. Shan, Y. Gao, and Q. Yang, "Effect of sulphur concentration on bioleaching of heavy metals from contaminated dredged sediments" Environmental Technology, vol. 30, no. 12, pp. 1241-1248, 2009. 